\title{
KAJIAN TERHADAP MANAJEMEN PENULISAN DAN PENERBITAN BUKU TEKS PELAJARAN KURIKULUM 2013
}

\author{
Benget Simamora \\ Program Studi Penerbitan, Jurusan Penerbitan \\ Politeknik Negeri Media Kreatif Jakarta \\ Surel: simamorabenget@gmail.com
}

\begin{abstract}
This research aims at exploring the management of writing and publishing the school textbooks in Curicullum 2013. Data are collected through interviews, observation, and documentation. Respondents in this reseach are the authors, editors, book designers, layouters, and illustrators of Curriculum 2013. The method used in this research is a qualitative method. Data are analyzed using a descriptive-qualitative analysis technique. This research can be used as inputs to address problems manuscript textbook procurement associated with Curicullum 2013, particularly in an effort to improve the quality of school textbooks of elementary, junior high or high school. The end result of this research is that the management of writing and publishing school textbooks in Curicullum 2013 have some problems, for instance there is standard operating procedures in writing and designing.
\end{abstract}

Keywords: writing management, publishing management, and school textbooks

\section{PENDAHULUAN}

Buku teks pelajaran sekolah (buku Pelajaran) adalah bagian penting dalam pelaksanaan pembelajaran sebab memudahkan guru melaksanakan pembelajaran dan membantu siswa dalam belajar sehingga buku acuan wajib oleh guru dan peserta didik dalam pembelajaran. Oleh karena itu, kemajuan suatu bangsa sangat dipengaruhi oleh jumlah judul buku yang diterbitkan dalam suatu negara dan jumlah oplah buku yang terserap oleh masyarakat negara bersangkutan. Tujuan Penilaian Buku Teks Pelajaran adalah
1. untuk menyediakan buku teks pelajaran layak-pakai agar dapat meningkatkan mutu pendidikan nasional;

2. meningkatkan mutu sumber daya perbukuan Indonesia;

3. melindungi peserta didik dari buku-buku yang tidak berkualitas;

4. meningkatkan minat dan kegemaran membaca.

Kriteria Mutu (Standar) Buku Teks Pelajaran adalah

1. kelayakan isi/materi

2. kelayakan penyajian

3. kelayakan bahasa

4. kelayakan kegrafikaan. 
Sejak tahun 1990 sampai saat sekarang, kebijakan pemerintah dalam pengadaan buku pelajaran sekolah telah silih berganti namun tetap mengalami masalah serius yang tidak pernah tuntas. Kebijakan pemerintah yang terakhir adalah tahun 2005, yaitu pengadaan buku sekolah elektronik (BSE). Konsep awal BSE bertujuan agar seluruh siswa di tanah air dapat mengakses buku sekolah dengan mudah dan harga murah, namun faktanya bertolak belakang belakang dengan harapan (Penelitian polimedia kerjasama Puskurbuk, 2011). Tahun 2013 pengadaan buku sekolah sepenuhnya ditangani oleh pemerintah, mulai dari pengadaan naskah sampai distribusi. Pengadaan buku tersebut telah terlaksana dengan cukup baik namun disadari bahwa di sana sini masih perlu perbaikan dalam proses penerbitannya.

Berdasarkan pengalaman , pengamatan langsung, dan masukanmasukan dari para penulis, editor, kopieditor, dan layouter di lapangan, maka tim peneliti merasa perlu mengadakan kajian terhadap manajemen penulisan dan penerbitan buku sekolah kurikulum 2013. Manajemen penulisan dan manajemen penerbitan sangat berkaitan dengan kualitas buku pelajaran dan ketersediaan buku pelajaran. Pemerintah telah mengeluarkan Permendikbud Nomor 71 tahun 2013 tentang buku teks pelajaran wajib dan PP 32 tahun 2013 yang di dalamnya mengatur mekanisme penilaian buku teks pelajaran.

Mulai Kurikulum 2013 pengadaan buku sekolah sepenuhnya ditangani oleh pemerintah, mulai dari pengadaan naskah sampai distribusi yang tentunya berimbas pada ketersediaan buku pelajaran. Pengadaan buku teks pelajaran membutuhkan proses manajemen yang ketat agar kualitas buku terjaga. Proses manajemen yang dimaksud adalah manajemen penulisan dan manajemen penerbitan. Kedua proses itu merupakan proses yang berkesinambungan. Politeknik Negeri Media Kreatif sebagai Penyelia Penerbitan Buku Kurikulum 2013 telah berupaya melaksanakan proses penerbitan sesuai manajemen penerbitan yang seharusnya.

Kegiatan penelitian ini memiliki tujuan, yaitu sebagai berikut:

1. Untuk mengetahui pelaksanaan manajemen penulisan buku teks pelajaran tahun 2013 oleh Pemerintah serta dampak yang ditimbulkannya;

2. Untuk mengetahui pelaksanaan manajemen penerbitan buku teks pelajaran tahun 2013 oleh Pemerintah serta dampak yang ditimbulkannya.

Buku pelajaran adalah segala bentuk bahan yang digunakan untuk membantu pembelajaran di kelas. Buku pelajaran juga merupakan materi atau substansi pembelajaran (teaching material) yang digunakan oleh siswa dalam mencapai tujuan pembelajaran dan kompetensi yang 
dikuasai siswa dalam kegiatan pembelajaran. Menurut Garry R.Morison (2007: 200) "Dalam proses persiapan bahan ajar, kita selalu mempelajari hal yang baru, proses pendekatan ini adalah proses heuristic".

Gerlach dan Ely (1971) menjelaskan buku pelajaran yang efektif harus memenuhi ketepatan kognitif (cognitive appropriateness), tingkat berpikir (level of shopisication), biaya (cost), ketersediaan bahan (availability), dan mutu teknis (technical quality). Jolly dan Bolitho (Tomsilon, 1998: 96-97) mengajukan langkah-langkah pengembangan bahan ajar dengan mengidentifikasi kebutuhan materi yang perlu, mengeksplorasi kondisi lingkungan wilayah tempat bahan ajar yang digunakan, menentukan masalah atau topik yang sesuai dengan kenyataan yang ada di lingkungan peserta didik untuk diajarkan, memilih pendekatan latihan dan aktivitas serta pendekatan prosedur pembelajaran, dan menulis rancangan materi bahan ajar. Adapun kriteria mutu haruslah memiliki kelayakan dalam isi atau materi, penyajian, bahasa, dan kegrafikaan.

Guru memiliki potensi menyusun buku teks karena sebenarnya guru adalah salah satu sumber belajar yang tak tergantikan. Di dalam buku teks terdapat materi, penyajian, dan bahasa yang biasa digunakan oleh guru dalam proses pembelajaran. Langkah-langkah menyusun buku teks secara terperinci disajikan sebagai berikut, a)1. Menyusun Silabus Penulisan Buku. Lakukan analisis SKL (standar kompetensi lulusan), KI (kompetensi inti), dan KD (kompetensi dasar).

b) Lakukan analisis karakteristik peserta didik sebagai informasi untuk menyesuaikan penyajian di dalam buku teks.

Tentukan tujuan pembelajaran.

c)2. Tentukan asesmen yang dilakukan pada proses pembelajaran dan akan dituliskan di dalam buku.

3. Lakukakakan pengembangan strategi instruksional.

d)4. Lakukan penentuan alat, bahan, dan media pembelajaran yang akan digunakan.

e)5. Membuat Pola Buku .Pola buku merupakan kerangka bentuk buku yang berisi hal-hal yang secara konsisten terdapat di dalam buku. Penyusun buku teks harus menentukan strategi instruksional yang dimuat dalam buku. Strategi instruksional terdiri atas kegiatan pembukaan, kegiatan inti, dan kegiatan penutup.

f)6. Membuat Outline Buku

7. Menulis isi buku sesuai kerangka isi yang sudah disusun.

g)8. Proses inilah yang merupakan proses inti dalam penulisan buku karena pada proses ini seluruh substansi yang merupakan isi buku harus dituliskan dengan baik agar dapat dipahami oleh pembaca.

h)9. Menyerahkan naskah kepada penerbit untuk diolah menjadi 
naskah buku yang siap
diterbitkan.

Peraturan Pemerintah No 32 tahun 2013 menyatakan bahwa buku teks harus dinilai kelayakannya oleh BSNP atau ahli yang ditunjuk oleh Kemendikbud. Pamusuk Eneste (2005) menjelaskan agar buku sekolah bisa memperoleh pengesahan dari Dirjen Dikdasmen ada empat unsur yang dinilai dari buku sekolah yaitu segi isi atau materi, segi dasar atau haluan negara dan keamanan nasional, segi bahasa dan segi fisik atau grafika.

Manajemen penerbitan memegang peranan sentral dalam proses pengadaan naskah mentah buku hingga sampai ke tangan konsumen. Sebuah penerbit buku harus terintegrasi dengan penulis, editor, desainer, ilustrator, dan layouter, percetakan, dan distributor. Bambang Trim memaparkan lima kegiatan dasar editing dalam memeriksa kelayakan naskah (2009: 34-35) yaitu pemakluman, perbaikan, pengubahan, pengurangan dan penambahan. Lebih lanjut ugas pokok editor penerbit buku menurut Pamusuk Eneste (2012: 10) adalah merencanakan naskah yang akan diterbitkan, mencari naskah yang akan diterbitkan, mempertimbangkan naskah yang masuk ke penerbit, dan menyunting naskah dari segi isi atau materi.

Hasil penelitian yang dilakukan oleh PoliMedia di Aceh, Sulawesi utara, Nusa Tenggara Timur, Irian Jaya, dan Ambon tahun 2011 membuktikan bahwa program buku sekolah elektronik tidak berjalan dengan baik. Bahkan terjadi penyimpangan anggaran yang sangat memprihatinkan. Era 2013 untuk pengadaan buku pelajaran kurikulum 2013 direncanakan gratis untuk semua siswa dengan tujuan diperoleh buku yang berkualitas untuk menciptakan generasi emas untuk 25 tahun ke depan.

Pekerjaan di bagian departemen editorial meliputi merencanakan program buku-buku yang akan diterbitkan maupun direvisi, menyeleksi naskah yang masuk untuk dinilai kelayakan terbitnya, menilai kesesuaian naskah dengan kurikulum, dan mengolah naskah. Naskah yang layak diterbitkan akan segera diolah dan naskah yang tidak layak terbit akan dikembalikan kepada penulisnya. Naskah diolah dan diramu dari segi konsep materi, penyajian, bahasa, desain isi, dan ilustrasi sehingga enak dibaca dan mudah dipahami. Prosesnya mulai dari data entry, layout, dan proses editing sebanyak tiga kali. Selanjutnya naskah yang sudah siap digodok oleh editor diteruskan ke bagian produksi untuk dibuatkan print dummy. Print dummy disebar ke kontributor untuk ditelah isinya dari segi materi, bahasa, serta tata letak. Apabila proses editorial telah selesai, bagian produksi menyiapkan proses pencetakan. Secara skematis proses penulisan dan pencetakan buku teks, dapat dilihat pada Gambar 1:

Ilustrasi pada dasarnya dipergunakan untuk memperjelas 
pesan atau informasi yang disampaikan. Menurut B.P. Sitepu (2012: 151) fungsi ilustrasi adalah menarik perhatian pembaca, membuat konsep lebih konkret, menghindarkan istilah-istilah teknis, menjelaskan konsep visual, dan menjelaskan konsep spasial. Pemahaman mengenai tata letak yaitu pengaturan letak-letak antara teks dan elemen visual (gambar, ilustrasi, tabel, grafik, dan lain-lain). Sedangkan menurut Kamus Besar Bahasa Indonesia (2008:1409) tata letak adalah pengaturan, penempatan, dan penataan unsur grafika pada halaman atau seluruh barang cetakan supaya yang disajikan kelihatan menarik dan mudah dibaca.

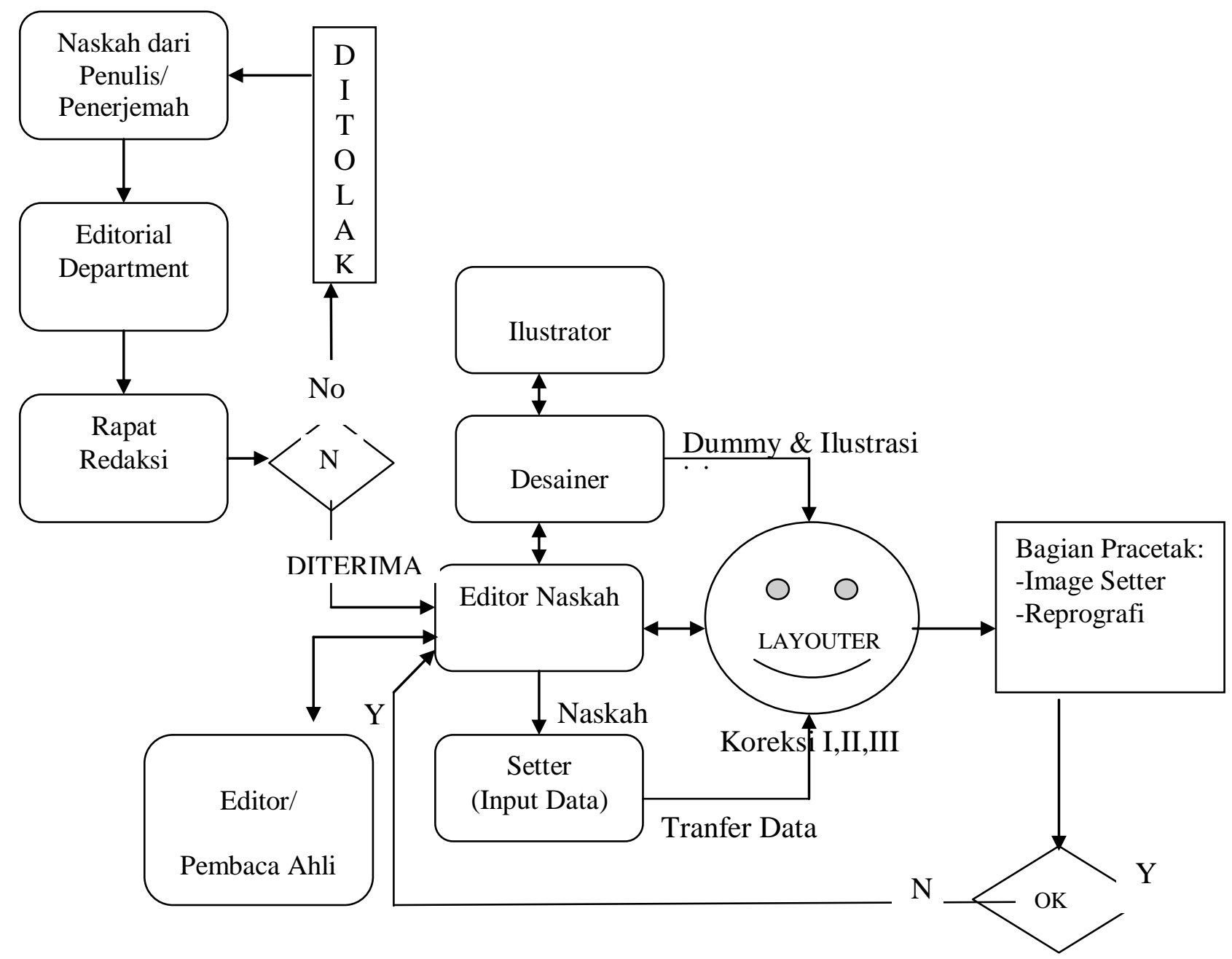

Gambar 1 Proses pPenulisan dan pPenerbitan bBuku tTeks

\section{METODE PENELITIAN}

Dalam penelitian ini pendekatan yang dilakukan adalah pendekatan kualitatif untuk mengetahui dinamika gambaran manajemen penulisan dan penerbitan buku teks. Penelitian ini juga menggunakan pendekatan kuantitatif yang digunakan untuk menganalisis masalah penelitian melalui angket 
yang telah disebar dengan analisis prosentasi. Peneliti bertindak sebagai pengumpul data dan instrumen aktif dalam mengumpulkan data-data di lapangan. Instrumen penting lain selain manusia adalah berbagai bentuk alat bantu dan dokumentasi yang bisa membantu suksesnya tujuan penelitian namun berfungsi sebagai instrumen pendukung. Kehadiran peneliti bertemu langsung dan keterlibatan yang aktif dengan responden merupakan sayarat mutlak dalam penelitian kualitatif.

Lokasi penelitian adalah Pulau Jawa dengan metode pengambilan data yaitu metode wawancara. Informasi yang diperlukan adalah berupa kata-kata yang diungkapkan subjek secara langsung sehingga dapat dengan jelas menggambarkan perasaan subjek penelitian dan mewakili kebutuhan informasi dalam penelitian. Adapun aspek yang ingin diungkap peneliti melalui wawancara dalam penelitian ini adalah hal-hal yangberhubungan dengan penulisan dan penerbitan buku teks.

Sumber data utama dalam penelitian diperoleh melalui pengamatan atau wawancara. Peneliti menggunakan data-data untuk menggali informasi tentang bagaimana penulis direkrut, bagaimana mekanisme mendapat naskah yang berkualitas, bagaimana mekanisme editorial, dan bagaimana mekanisme proses desain, ilustrasi, dan layout buku dilaksanakan. Data sekunder dalam penelitian ini adalah data-data yang berkaitan dengan dokumentasi, naskah, buku-buku- buku, majalah, buletin, hasil studi, dan semisalnya. Peneliti menggunakan data sekunder untuk memperkuat penemuan yang diperoleh melalui pengamatan langsung atau wawancara langsung.

Analisis data dalam penelitian ini menggunakan metode kualitatif. Tahapan analisis tersebut adalah: pengumpulan data, reduksi data, penyajian data, dan pengambilan keputusan (verifikasi). Setelah melalui tahap-tahap tersebut, selanjutnya peneliti mengolah dan menganalisis dengan menggunakan metode deskriptif-kualitatif tanpa menggunakan angka-angka. Selain itu juga digunakan analisis kuantitatif untuk menganalisis angket dengan metode prosentasi. Metode kuantitatif digunakan untuk mendukung metode kualitatif.

\section{HASIL DAN PEMBAHASAN}

\section{Penulisan Buku Teks Pelajaran Kurikulum 2013}

Penulisan Buku Teks Pelajaran Kurikulum 2013 Tahap I dikhususkan pada buku-buku yang digunakan untuk jenjang kelas I, IV, VII, dan X. Penulisan Buku Teks Pelajaran Kurikulum 2013 Tahap II dikhususkan pada buku-buku yang digunakan untuk jenjang kelas II, V, VIII, dan XI, ditambah kelas X mata pelajaran selain Bahasa Indonesia, Matematika, dan Sejarah. Khusus untuk SMA, bidang studi peminatan, pengadaan naskahnya diserahkan kepada penerbit swasta dengan mekanisme penilaian yang diatur oleh Kemendikbud. 
Berdasarkan hasil wawancara yang kami lakukan kepada perwakilan penulis, penentuan penulis dilakukan oleh Puskurbuk. Para penulis diundang Puskurbuk dan diberi penjelasan bahwa para penulis ditugaskan untuk menulis buku sesuai jenjang dan mata pelajaran. Khusus untuk penulis SD, para penulis merupakan gabungan dari penulis-penulis berbagai mata pelajaran. Hal itu disebabkan pendekatan pembelajaran di SD yang menggunakan pendekatan tematik, yaitu sebuah pendekatan yang memadukan berbagai mata pelajaran dalam satu kegiatan pembelajaran.

Penulis buku pelajaran ditunjuk oleh penerbit berdasarkan kredibilitas, keahlian, dan kesesuaian dengan bidang mata pelajaran. Penulis menulis naskah sesuai dengan yang diminta oleh penerbit. Dalam hal naskah layak atau tidak layak, jika naskah adalah naskah pesanan, maka pemesan harus mengusahakan naskah itu layak terbit. Hasil angket yang disebarkan kepada 100 orang penulis menjelaskan sebanyak $71 \%$ responden menyatakan tidak ada unsur nepotisme dalam rekrutmen. Sebesar $93 \%$ penulis merasa kompeten dalam menulis buku ajar.

Proses perancangan dilakukan penulis dengan membuat kerangka penulisan berdasarkan indikatorindikator yang dirumuskan dari kompetensi dasar. Khusus untuk penulisan buku SD, karena menggunakan pendekatan tematik, maka penulis melakukan pemetaan semua $\mathrm{KD}$ ke dalam tema dan subtema yang disajikan. Dalam hal ini penulis buku teks pelajaran kurikulum 2013 sudah melaksanakan sesuai prosedur yang berlaku. Dalam merancang naskah, penulis yang mengacu kepada kurikulum mencapai $85.71 \%$. Naskah yang didapat dikoreksi oleh pakar atau ahlinya menduduki $92.86 \%$ dari responden. Hal ini sangat menggembirakan karena manajermen penulisan buku sudah mendekati yang dipersyaratkan pada penulisan buku teks pelajaran sekolah. Namun hanya sebesar $35.71 \%$ penulis yang menjawab memiliki SOP (Standar Operasional Prosedur) dalam penulisan. Secara terperinci hasil kuesioner dapat dilihat pada Tabel 1.

Analisis hasil kuesioner menunjukkan standar operasional prosedur dalam penulisan perlu mendapat perhatian yang serius. Demikian juga proses penulisan, rekrutmen penulis, dan perancangan naskah. Rekrutmen penulis lebih baik dibuat bersaing dengan diadakan sayembara penulisan buku pelajaran. Pada proses perancangan naskah sudah harus melibatkan ahli untuk memberikan penilaian agar menghindari proses perubahan rancangan ketika naskah sudah ditulis. Artinya, setelah perumusan indikator dan pembuatan ouline buku, PUSKURBUK sebagai pengelola naskah sudah melibatkan para ahli untuk mereview rancangan naskah. 
Tabel 1 Hasil kKuesioner pPenulis

\begin{tabular}{|c|l|r|r|}
\hline \multirow{2}{*}{ NO } & \multicolumn{1}{|c|}{ PERNYATAAN } & \multicolumn{2}{|c|}{ Persentasi jawaban } \\
\cline { 2 - 4 } & \multicolumn{1}{|c|}{ Ya(\%) } & Tidak(\%) \\
\hline $\mathbf{1}$ & $\begin{array}{l}\text { Tidak ada unsur nepotisme dalam rekrutmen } \\
\text { penulis }\end{array}$ & 71.43 & 28.57 \\
\hline $\mathbf{2}$ & Saya merasa kompeten dalam menulis buku ajar & 92.86 & 7.14 \\
\hline $\mathbf{3}$ & Saya menjadi penulis buku ajar ini melalui teman & 14.29 & 85.71 \\
\hline $\mathbf{4}$ & $\begin{array}{l}\text { Ada SOP/Standar Operasional Prosedur dalam } \\
\text { penulisan }\end{array}$ & 35.71 & 64.29 \\
\hline $\mathbf{5}$ & $\begin{array}{l}\text { Naskah yang didapat apakah dikoreksi oleh pakar } \\
\text { atau ahlinya }\end{array}$ & 92.86 & 7.14 \\
\hline $\mathbf{6}$ & Penentuan penulis dilakukan oleh Puskurbuk & 85.71 & 14.29 \\
\hline $\mathbf{7}$ & $\begin{array}{l}\text { Proses penentuan penulis dilaksanakan secara } \\
\text { demokratis }\end{array}$ & 71.43 & 28.57 \\
\hline $\mathbf{8}$ & $\begin{array}{l}\text { Proses perancangan naskah dilasanakan secara } \\
\text { bertahap }\end{array}$ & 85.71 & 14.29 \\
\hline $\mathbf{9}$ & Waktu perancangan naskah lebih dari 1 bulan & 64.29 & 35.71 \\
\hline $\mathbf{1 0}$ & $\begin{array}{l}\text { Dalam merancang naskah, penulis mengacu } \\
\text { kepada kurikulum }\end{array}$ & 85.71 & 14.29 \\
\hline
\end{tabular}

Artikel dari internet mempelajari aspek yang perlu diperhatikan dalam menulis buku pelajaran. Beberapa artikel tersebut dapat dilihat sebagai berikut:pada Tabel 2.

Berdasarkan analisis penelitian dikemukakan bahwa penulisan buku teks pelajaran dikerjakan dengan memperhatikan sistematika penulisan yang dibuat dengan mengacu pada kurikulum, pendekatan pembelajaran, karakteristik pembelajar, dan perkembangan teknologi. Penulisan buku teks pelajaran kurikulum 2013 sejalan dengan hasil penelitian tersebut bahwa penulisan buku diawali dengan pembuatan sistematika buku berdasarkan kurikulum yang berlaku. Selain itu, pada penulisan kurikulum 2013 juga menggunakan pendekatan pembelajaran berdasarkan perkembangan ilmu dan teknologi pendidikan, yaitu pendekatan scientific.

Berdasar wawancara maka penulis dalam menulis buku teks pelajaran sistematikanya harus menyelaraskan antara kerangka tulisan, kurikulum dan tujuan pembelajaran sehingga pembaca dan pengguna buku dapat mudah memahami isi dan maksud dari pembelajaran. Kaidah-kaidah dalam penulisan buku teks tersebut harus sesuai dengan tujuan buku dan mengacu pada kurikulum sehingga dapat dijadikan sumber informasi 
yang akurat serta relevan bagi siswa untuk belajar di kelas maupun di rumah. Teknologi pendidikan berperan aktif dalam penulisan buku teks pelajaran karena pada dasarnya pengembangan buku teks pelajaran mengacu pada pengembangan bahan ajar yang merupakan bagian dari instructional design.

Tabel 2 Artikel pPembuatan bBuku tTeks

\begin{tabular}{|c|c|c|c|c|}
\hline No. & Nama penulis & Judul artikel & Analisis & Sumber \\
\hline 1 & Agus Wuryanto & $\begin{array}{l}\text { Pembuatan } \\
\text { Buku Teks } \\
\text { Pelajaran }\end{array}$ & $\begin{array}{l}\text { Sistematika } \\
\text { penulisan buku teks } \\
\text { pelajaran di awali } \\
\text { dengan } \\
\text { penyusunan } \\
\text { kerangka tulisan } \\
\text { berdasarkan konsep } \\
\text { dasar ilmu yang } \\
\text { bersangkutan }\end{array}$ & $\begin{array}{l}\text { http://aguswury } \\
\text { anto.wordpress. } \\
\text { com/2010/09/0 } \\
\text { 2/pembuatan- } \\
\text { buku-teks- } \\
\text { pelajaran/ }\end{array}$ \\
\hline 2 & Sawali & $\begin{array}{l}\text { Menulis Buku } \\
\text { Teks }\end{array}$ & $\begin{array}{l}\text { Sistematika } \\
\text { penulisan buku teks } \\
\text { pelajaran di mulai } \\
\text { dengan menetapkan } \\
\text { tujuan } \\
\text { pembelajaran } \\
\text { terlebih dahulu }\end{array}$ & $\begin{array}{l}\text { http://sawali.inf } \\
\text { o/2007/07/15/m } \\
\text { enulis-buku- } \\
\text { teks/ }\end{array}$ \\
\hline 3 & Sholahudin & $\begin{array}{l}\text { Menulis Buku } \\
\text { Pelajaran }\end{array}$ & $\begin{array}{l}\text { Sistematika } \\
\text { penulisan buku teks } \\
\text { pelajaran dilihat } \\
\text { dari kurikulum }\end{array}$ & $\begin{array}{l}\text { http://sholahud } \\
\text { din.edublogs.or } \\
\text { g/2010/05/01/m } \\
\text { enulis-buku- } \\
\text { pelajaran/ }\end{array}$ \\
\hline 4 & $\begin{array}{l}\text { Masnur } \\
\text { muslich }\end{array}$ & $\begin{array}{l}\text { Hakikat dan } \\
\text { Fungsi Buku } \\
\text { Teks }\end{array}$ & $\begin{array}{l}\text { Sistematika } \\
\text { penulisan } \\
\text { berdasarkn } \\
\text { pendekatan } \\
\text { pembelajaran \& } \\
\text { karakteristik } \\
\text { pemelajar }\end{array}$ & $\begin{array}{l}\text { http://masnur- } \\
\text { muslich.blogsp } \\
\text { ot.com/2008/10 } \\
\text { /hakikat-dan- } \\
\text { fungsi-buku- } \\
\text { teks.html }\end{array}$ \\
\hline 5 & Ramlan & $\begin{array}{l}\text { Penilaian Buku } \\
\text { Teks Pelajaran }\end{array}$ & $\begin{array}{l}\text { Sistematika } \\
\text { penulisan } \\
\text { berdasarkn masalah } \\
\& \text { Perkembangan } \\
\text { Teknologi }\end{array}$ & $\begin{array}{l}\text { http://ramlannar } \\
\text { ie.wordpress.co } \\
\text { m/2011/10/22/p } \\
\text { enilaian-buku- } \\
\text { teks-pelajaran- } \\
\text { bahasa- }\end{array}$ \\
\hline
\end{tabular}


indonesia-smp/

Berdasarkan analisis penelitian dikemukakan bahwa penulisan buku teks pelajaran dikerjakan dengan memperhatikan sistematika penulisan yang dibuat dengan mengacu pada kurikulum, pendekatan pembelajaran, karakteristik pembelajar, dan perkembangan teknologi. Penulisan buku teks pelajaran kurikulum 2013 sejalan dengan hasil penelitian tersebut bahwa penulisan buku diawali dengan pembuatan sistematika buku berdasarkan kurikulum yang berlaku. Selain itu, pada penulisan kurikulum 2013 juga menggunakan pendekatan pembelajaran berdasarkan perkembangan ilmu dan teknologi pendidikan, yaitu pendekatan scientific.

Hasil analisis kuesioner dan wawancara maka penulis dalam menulis buku teks pelajaran sistematikanya harus menyelaraskan antara kerangka tulisan, kurikulum dan tujuan pembelajaran sehingga pembaca dan pengguna buku dapat mudah memahami isi dan maksud dari pembelajaran. Kaidah-kaidah dalam penulisan buku teks tersebut harus sesuai dengan tujuan buku dan mengacu pada kurikulum sehingga dapat dijadikan sumber informasi yang akurat serta relevan bagi siswa untuk belajar di kelas maupun di rumah. Teknologi pendidikan berperan aktif dalam penulisan buku teks pelajaran karena pada dasarnya pengembangan buku teks pelajaran mengacu pada pengembangan bahan ajar yang merupakan bagian dari instructional design.

\section{Manajemen Penerbitan Buku Teks Pelajaran 2013}

Khusus untuk penerbitan buku teks pelajaran kurikulum 2013 tahap pertama, supervisi penerbitan dilakukan oleh PoliMedia. Dalam menjalankan fungsinya sebagai penyelia penerbitan, PoliMedia harus menyediakan editor, desainer atau layouter, dan ilustrator. Berikut ini adalah hasil kuesioner untuk pelaku proses penerbitan buku teks kurikulum 2013.

Hasil kuesioner terhadap 15 orang editor menyatakan sebanyak $69.23 \%$ responden sesuai dengan persyaratan editor. Editor yang mengikuti proses editing sesuai aturan sebesar $38.46 \%$. Para editor yang merasakan keamanan dan kenyamanan yang cukup baik serta tidak mengalami tekanan dalam mengedit buku hanya sebesar 15.38 $\%$. Para editor yang bekerja lebih dari 8 jam sehari mencapai $92.31 \%$ responden. Sebesar $84.62 \%$ editor pernah menerima naskah yang tidak lengkap atau utuh. Sebesar 92.31\% responden adalah para editor yang memiliki pengalaman teori dan praktis dalam dunia penerbitan dan sebanyak $\quad 84.62 \% \quad$ editor berkoordinasi dengan para ilustrator dan designer. Secara terperinci hasil kuesioner sebagai berikutditampilkan pada Tabel 3.: 
Tabel 3 Hasil KKuesioner EEditor

\begin{tabular}{|c|c|c|c|}
\hline \multirow[t]{2}{*}{ No } & \multirow[t]{2}{*}{ Pernyataan } & \multicolumn{2}{|c|}{ Persentasi jawaban } \\
\hline & & Ya & tidak \\
\hline 1 & Para editor dipilih sudah sesuai persyaratan editor & 69.23 & 30.77 \\
\hline 2 & Proses editing sudah sesuai aturan editor & 38.46 & 61.54 \\
\hline 3 & $\begin{array}{l}\text { Para editor merasakan keamanan dan kenyamanan } \\
\text { yang cukup baik serta tidak mengalami tekanan } \\
\text { dalam mengedit buku }\end{array}$ & 15.38 & 84.62 \\
\hline 4 & Para editor bekerja lebih dari 8 jam/hari & 92.31 & 7.69 \\
\hline 5 & $\begin{array}{l}\text { Para editor menerima naskah buku yang telah } \\
\text { memenuhi standar keterbacaan }\end{array}$ & 61.54 & 38.46 \\
\hline 6 & $\begin{array}{l}\text { Editor pernah menerima naskah yang tidak } \\
\text { lengkap/utuh }\end{array}$ & 84.62 & 15.38 \\
\hline 7 & $\begin{array}{l}\text { Editor pernah menerima naskah yang mengandung } \\
\text { unsur sara }\end{array}$ & 23.08 & 76.92 \\
\hline 8 & $\begin{array}{l}\text { Editor pernah menerima naskah yang mengandung } \\
\text { kata-kata tidak sopan }\end{array}$ & 38.46 & 61.54 \\
\hline 9 & $\begin{array}{l}\text { Para editor adalah orang yang memiliki } \\
\text { pengalaman teori dan praktis dalam dunia } \\
\text { penerbitan }\end{array}$ & 92.31 & 7.69 \\
\hline 10 & $\begin{array}{l}\text { Di waktu-waktu tertentu, editor berkoordinasi } \\
\text { dengan para ilustrator dan designer }\end{array}$ & 84.62 & 15.38 \\
\hline
\end{tabular}

Dari pertanyaan terbuka didapatkan hasil bahwa $100 \%$ editor sesuai dengan bidangnya dan sebesar $100 \%$ editor menjawab diberi target penyelesaian pekerjaannya untuk 1 buku. Sebesar $69 \%$ editor bekerja sama dengan penulis. Sementara editor belum berpengalaman sebanyak $62 \%$ dan hanya 38\% editor yang sudah berpengalaman.

Analisis kuesioner dari responden diperoleh hasil bahwa persyaratan editor, proses editing, keamanan dan kenyamanan bekerja para editor, keadaan naskah yang akan disunting, naskah yang mengandung unsur sara, naskah yang mengandung kata-kata tidak sopan, perlu mendapat perhatian untuk pengadaan buku pelajaran pada tahap ke dua untuk tahun ajaran 2014/2015. Rekrutmen para editor buku pelajaran sekolah harus diseleksi dengan baik dan jelas. Kriteria perekrutan harus jelas dan dibuat bersaing sehingga didapat editor dengan kompetensi sesuai dengan jenis buku yang akan diedit.

Dari hasil kuesioner terhadap 30 orang ilustrator didapatkan bahwa responden yang mengikuti proses ilustrasi buku berdasarkan hasil rapat bersama tim mencapai $100 \%$. Sebanyak $100 \% \quad$ responden 
menjawab proses ilustrasi buku tidak mengikuti selera ilustrator. Para ilustrator dipilih hanya berdasarkan pengalaman hanya sebanyak $37.5 \%$ saja dan ilustrator yang berkoordinasi dengan editor sebesar $100 \%$.
Dari pertanyaan terbuka sebanyak $100 \%$ responden menjawab diberi target waktu, bekerjasama dengan editor, ilustrator bolak balik berjumpa dengan editor, dan ilustrator diberi target waktu untuk menyelesaikan 1 buku.

Tabel 4 Hasil KKuesioner IIlustrator

\begin{tabular}{clcc}
\hline No & \multicolumn{1}{c}{ Pernyataan } & \multicolumn{2}{c}{ Persentasi jawaban } \\
& & Ya & tidak \\
\hline 1 & Para ilustrator dipilih hanya berdasarkan pengalaman & 37.50 & 62.50 \\
\hline 2 & $\begin{array}{l}\text { Proses ilustratordipilih hanya berdasarkan latar } \\
\text { belakang dan pengalaman }\end{array}$ & 37.50 & 62.50 \\
\hline 3 & Para ilustrator dipilih apa adanya & 37.50 & 62.50 \\
\hline 4 & Proses ilustrasi buku mengikuti selera illustrator & 0.00 & 100.00 \\
\hline 5 & Proses ilustrasi buku ditetapkan berdasarkan hasil & & \\
& rapat bersama tim & 100.00 & 0.00 \\
\hline 6 & Ilustrator bekerja berdasarkan panduan & 87.50 & 12.50 \\
\hline 7 & Alur kerja ilustrator selalu berubah-ubah & 87.50 & 12.50 \\
\hline 8 & $\begin{array}{l}\text { Ilustrator berganti-ganti dalam menyelesaikan 1(satu) } \\
\text { buku }\end{array}$ & 87.50 & 12.50 \\
\hline 9 & Ilustrator berkoordinasi dengan editor & 100.00 & 0.00 \\
\hline 10 & Bentuk ilustrasi naskah buku selalu berubah-ubah & 75.00 & 25.00 \\
\hline & & & \\
\hline
\end{tabular}

Dari pertanyaan terbuka sebanyak $100 \%$ responden menjawab diberi target waktu, bekerjasama dengan editor, ilustrator bolak balik berjumpa dengan editor, dan i ilustrator diberi target waktu untuk menyelesaikan 1 buku.

Hasil analisis kuesioner para ilustrator diperoleh bahwa para ilustrator yang dipilih hanya berdasarkan pengalaman perlu mendapat perhatian yang serius agar ke depan didapat ilustrator yang handal dalam bidangnya. Perekrutan ilustrator yang berdasarkan latar belakang dan pengalaman perlu mendapat perhatian. Artinya bahwa untuk mendapatkan ilustrator yang handal tidak semudah yang dibayangkan. Ilustrasi yang berubahubah pun menjadi tantangan tersendiri yang harus dihadapi dengan kesabaran yang cukup memadai.

Dari kuesioner terhadap 30 orang designer maka responden yang berdasarkan latar belakang dan memiliki pengalaman dan designer (layout) bekerja berdasarkan panduan mencapai 100\%. Designer yang mengikuti proses design buku ditetapkan berdasarkan hasil rapat 
bersama tim, designer berkoordinasi dengan editor dan designer naskah buku selalu berubah-ubah sebanyak
90.91\% responden. Secara terperinci hasil kuesioner sebagai berikut:

Tabel 5 Hasil AAngket DDesigner

\begin{tabular}{clcc}
\hline No & \multicolumn{1}{c}{ Pernyataan } & \multicolumn{2}{c}{ Persentasi jawaban } \\
& & Ya & tidak \\
\hline 1 & Para designer dipilih hanya berdasarkan pengalaman & 72.73 & 27.27 \\
\hline 2 & $\begin{array}{l}\text { Para designer dipilih hanya berdasarkan latar belakang } \\
\text { dan pengalaman }\end{array}$ & 100.00 & 0.00 \\
\hline 3 & Para designer dipilih apa adanya & 9.09 & 90.91 \\
\hline 4 & Proses designer /layout buku mengikuti selera illustrator & 0.00 & 100.00 \\
\hline 5 & Proses designer /layout buku ditetapkan berdasarkan & & \\
& hasil rapat bersama tim & 90.91 & 9.09 \\
\hline 6 & Designer /layout bekerja berdasarkan panduan & 100.00 & 0.00 \\
\hline 7 & Alur kerja designer /layout selalu berubah-ubah & 81.82 & 18.18 \\
\hline 8 & $\begin{array}{l}\text { Designer /layout berganti-ganti dalam menyelesaikan } \\
\text { 1(satu) buku }\end{array}$ & 63.64 & 36.36 \\
\hline 9 & Designer /layout berkoordinasi dengan editor & 90.91 & 9.09 \\
\hline 10 & Designer /layout naskah buku selalu berubah-ubah & 90.91 & 9.09 \\
\hline
\end{tabular}

Angket terbuka tentang designer yang sudah sesuai dengan bidang keahliannya, designer sudah punya pengalaman, designer yang diberi target waktu, designer yang bekerjasama dengan editor dan ilustrator, sesuai keahlian mencapai sebesar $84.62 \%$. Rata-rata designer menyelesaikan pekerjaannya selama 7 hari. Hasil analisis kuesioner terhadap designer diperoleh bahwa ada tiga hal yang perlu mendapat perhatian, yaitu rekrutmen designer dilakukan apa adanya, designer bergani-ganti dalam menyelesaikan satu buku. Kedua hal ini agar mendapat perhatian yang serius untuk perekrutan designer pada penulisan buku pelajaran tahap dua.
Designer yang berganti-ganti dalam proses pengerjaan satu judul naskah akan menghasilkan buku yang kurang baik.

\section{PENUTUP}

Penelitian ini menyimpulkan manajemen penulisan pada buku teks pelajaran 2013 sudah baik, meskipun diperlukan ada SOP (Standar Operasional Prosedur) penulisan dan juga review ahli dalam proses naskah dan hasil rancangan naskah. Mutu dan kualitas buku dapat tercapai apabila alur kerja dalam manajemen penulisan benar-benar diperhatikan, terutama dalam hal revisi naskah dengan meliibatkan para ahli yang menilai buku (penilaian oleh BSNP 
atau tim yang ditunjuk oleh Kemendikbud). Dalam hal manajemen penulisan buku agar diperhatikan kiriteria penulis. Sebaiknya dalam memilih penulis buku pelajaran hendaknya diadakan terlebih dahulu lomba penulisan buku pelajaran sehingga didapat penulis yang benar-benar memiliki kompetnsi yang paling baik.

Namun penelitian juga menyimpulkan bahwa manajemen penerbitan buku teks pelajaran 2013 masih perlu mendapat perhatian terutama dalam hal perekrutan editor, ilustrator, layouter, dan desainer. Alur naskah dalam proses penerbitan buku perlu mendapat perhatian khusus agar tidak terjadi pengerjaan naskah dengan koreksi berkali-kali. Dalam hal proses penerbitan buku, perlu ada rekrutmen editor yang memenuhi syarat. Demikian juga untuk para desainer, layouter, dan ilustrator perlu rekrutmen dengan memperhatikan keahlian dan pengalaman mereka sesuai bidangnya.

\section{DAFTAR RUJUKAN}

Departemen Pendidikan Nasional. 2008. Kamus Besar Bahasa Indonesia Edisi Keempat. Jakarta: Gramedia Pustaka Utama.

Eneste. Panusuk. 2005. Buku Pintar Penyuntingan Naskah Edisi II. Jakarta: Gramedia.

Garry, R. Morison. 2007. Designing Efective Instruction. John Wiley \& Sonn.
Gerlach dan Ely dkk.1980. Teaching \& Media: A Systematic Approach. Second eEdition. Englewood Cliffs, New Jersey: Prentice Hall, Inc.

Trim, Bambang. 2009. Taktis Menyunting Buku. Bandung: Maximalis.

Trim, Bambang. 2012. Apa dan Bagaimana Menerbitkan Buku. IKAPI Jakarta.

Tomsilon, Brian(ed). 1998. Material Development in lLanguage Tteaching. Cambridge University. 